\title{
PENGARUH MODEL PEMBELAJARAN TEAMS GAMES TOURAMENTS DENGAN PERMAINAN MONOPOLI TERHADAP HASIL BELAJAR MATEMATIKA DI SMK KOLESE TIARA BANGSA
}

\author{
Puji Suryani*, Nina Agustyaningrum **, Nailul Himmi Hasibuan \\ Program Studi Pendidikan Matematika, Fakultas Keguruan Dan Ilmu Pendidikan \\ Universitas Riau Kepulauan, Batam, Kepulauan Riau \\ E-mail:*pujisuryani53@gmail.com,**agustyaningrum@gmail.com
}

\begin{abstract}
Abstrak. Hasil belajar siswa sangat dipengaruhi oleh pemilihan dan penggunaan model pembelajaran. Tujuan dalam penelitian ini adalah untuk mengetahui: (1) Pengaruh model pembelajaran Teams Games Tournament (TGT) dengan permainan monopoli terhadap hasil belajar matematika siswa kelas X di SMK Kolese Tiara Bangsa, (2) Pengaruh pembelajaran konvensional terhadap hasil belajar matematika siswa kelas X di SMK Kolese Tiara Bangsa, (3) Perbedaan hasil belajar matematika siswa kelas X di SMK Kolese Tiara Bangsa dengan menggunakan model pembelajaran TGT dengan permainan monopoli dan pembelajaran konvensional. Jenis penelitian adalah kuasi eksperimen. Populasi penelitian adalah seluruh siswa kelas X dan teknik pengambilan sampel menggunakan Purposive Sampling, dengan rincian kelas X MM sebagai kelas eksperimen dan X TKJ sebagai kelas kontrol. Instrumen essai test sebanyak 10 soal yang telah valid dan reliabel $(\mathrm{r}=0,69)$. Analisis data menggunakan one sampel $t$-test untuk uji hipotesis 1 dan 2 sedangkan untuk hipotesis 3 menggunakan uji independent sampel t-test. Hasil penelitian menunjukkan: (1) Terdapat pengaruh hasil belajar pada siswa yang diberikan model pembelajaran TGT dengan permainan monopoli $t_{\text {hitung }}(2,207)>t_{\text {tabel }}(2,039)$. (2) Tidak terdapat pengaruh hasil belajar pada siswa yang diberikan pembelajaran konvensional $t_{\text {hitung }}(-0,907)<t_{\text {tabel }}(2,093)$. (3) Terdapat perbedaan pengaruh model pembelajaran Teams Games Tournament (TGT) dengan permainan monopoli dan model pembelajaran konvensional terhadap hasil belajar matematika siswa $t_{\text {hitung }}(2,069)>t_{\text {tabel }}(2,008)$.

Kata Kunci : Model Pembelajaran, Teams Games Tournamen (TGT), Permainan Monopoli Pembelajaran Konvensional, Hasil Belajar Matematika
\end{abstract}

\begin{abstract}
Students' learning outcomes significantly affected by selection and use of learning model. This research aims to find out: (1) The influence of TGT learning model with game monopoly against the results of learning math grade SMK X Kolese Tiara Bangsa, (2) The effect of conventional learning mathematics learning outcomes grade SMK X Kolese Tiara Bangsa, (3) The difference in the mathematics learning outcomes grade SMK X Kolese Tiara Bangsa by using the TGT learning model and the game monopoly and conventional learning. The type of this research was quasi experimental. The population of this research was all ten grade students and the techniqeue of collecting sample used Purposive sampling, in which X MM class as an experimental class and X TKJ class as an control class. Instrument this study essay test as many as 10 questions that have been valid and reliable. Data analysis using one sample t-test to test hypotheses 1 and 2 while hypothesis 3 using independent sample t-test. Research results showed: (1) There is an effect of learning outcomes on students who were given the Teams model Games Tournament (TGT) learning with a monopoly game $t_{\text {hitung }}(2.207)>t_{\text {tabel }}(2.039)$. (2) There is no effect of result learning in students who are given conventional learning $t_{\text {hitung }}(-0.907)<t_{\text {tabel }}(2.093)$. (3) There is a difference in the effect of learning Teams model Games Tournament (TGT) with monopoly game and conventional learning models on student mathematic learning outcomes $t_{\text {hitung }}(2.069)>t_{\text {tabel }}(2.008)$.

Key words : Learning Model, Teams Games Tournamen (TGT), Monopoly Game, Conventional Learning, Mathematics Learning Outcomes.
\end{abstract}




\section{Pendahuluan}

Pendidikan adalah usaha sadar yang dengan sengaja dirancang untuk mencapai tujuan yang telah ditetapkan (Roqimah, 2011). Salah satu pendidikan di Indonesia adalah jalur pedidikan formal dan salah satu unit pendidikan yang menyediakan pendidikan formal adalah Sekolah Menengah Kejuruan (SMK). Sekolah Menengah Kejuruan (SMK) mengemban visi untuk menyiapkan sumber daya manusia (SDM) atau tenaga kerja yang terlatih dan terdidik sehingga memiliki kemampuan dan siap untuk bekerja sesuai bidangnya. Dalam rangka menyiapkan siswa yang bermutu dan memiliki kemampuan, siswa SMK dibekali dengan ilmu pengetahuan, teknologi dan seni (IPTEKS). Dalam upaya mendukung penguasaan IPTEKS, peserta didik harus dibekali dengan ilmu dasar salah satunya matematika. Tapi pada kenyataannya hasil belajar matematika di SMK Kolese Tiara Bangsa masih rendah, hal ini dapat dilihat dari rata-rata nilai yang masih rendah pada Tabel 1.

Tabel.1 Nilai Ujian Matematika Siswa

\begin{tabular}{ccccccc}
\hline No & Kelas & Jumlah siswa & KKM & Tuntas & Tidak Tuntas & Rata-Rata Nilai \\
\hline 1 & X MM & 32 & 70 & $0 \%$ & $100 \%$ & 27,19 \\
2 & X TKJ & 20 & 70 & $5 \%$ & $95 \%$ & 50,29 \\
3 & X OTKP & 17 & 70 & $15 \%$ & $85 \%$ & 60,20 \\
4 & X AK & 25 & 70 & $40 \%$ & $60 \%$ & 71,65 \\
\hline
\end{tabular}

Sumber : Waka Kurikullum

Berdasarkan hasil observasi di SMK Kolese Tiara Bangsa pada kelas X menunjukkan cara guru mengajar yaitu dengan model konvensional sehingga siswa menjadi bosan, mengantuk, pasif dalam mengikuti pembelajaran dan sering ijin ke toilet secara bergantian. Model yang digunakan guru dalam pembelajaran dikelas kurang bervariasi sehingga siswa tidak memperhatikan guru menjelaskan. Dan masih ada siswa yang malas belajar secara mandiri atau mengerjakan tugas yang diberikan oleh guru mata pelajaran karena tidak memahami materi yang diajarkan.

Peneliti juga mewawancarai siswa untuk mendapatkan informasi tentang masalah yang dialami, beberapa guru memberikan materi terlalu cepat sehingga siswa yang belum paham kurang berpartisipasi dalam mengerjakan soal latihan. Ada siswa yang berpendapat bahwa mereka bosan dan terbebani oleh jadwal mata pelajaran yang terlalu padat atau banyak karena sekolah menggunakan sistem semi blok. Selain jadwal yang terlalu padat siswa juga berpendapat model pembelajaran yang biasa digunakan oleh guru mata pelajaran membosankan. Peneliti juga memperoleh data dan keterangan dari guru bidang studi, mata pelajaran matematika masih menjadi pelajaran yang hasil belajarnya rendah dan ada perbedaan keaktifan yang terlihat dengan jelas siswa yang memiliki kapasitas akademik tinggi dengan siswa yang memiliki kapasitas akademik rendah. Guru bidang studi masih menggunakan pembelajaran konvensional dengan alasan jika model pembelajaran yang digunakan sesuai kurikulum 2013 materi pembelajaran tidak akan selesai sesuai program tahunan (PROTA) yang sudah disusun. Guru mata pelajaran 
juga memberikan keterangan bahwa saat proses pembelajaran tidak adanya media pembelajaran yang bisa digunakan sehingga membuat siswa cenderung kurang aktif dalam mengikuti pelajaran.

Guru memiliki peran sangat penting pada saat proses pembelajaran. Selain itu mata pelajaran matematika juga sering dipandang sebagai mata pelajaran yang sulit, tidak menarik, dan membosankan. Dalam hal ini guru harus pandai dalam pemilihan atau penggunaan model dan media pembelajaraan. Pada saat pembelajaran matematika diharapkan guru dapat menyampaikan materi dengan strategi yang tepat, sehingga siswa dapat menyalurkan pengetahuannya sendiri dan melibatkan diri secara aktif dalam proses pembelajaran (Simanungkalit, 2014).

Salah satu cara yang dapat dilakukan guru untuk meningkatkan hasil belajar matematika adalah dengan cara menerapkan model pembelajaran TGT. Model pembelajaran TGT adalah yang mudah diterapkan, melibatkan aktivitas seluruh siswa tanpa harus ada perbedaan status, melibatkan peran siswa sebagai tutor sebaya dan mengandung unsur permainan dan reinforcement (Shoimin, 2014). Model TGT dapat membantu siswa mereview dan menguasai materi pembelajaran, aktivitas belajar dengan permainan yang dirancang dalam pembelajaran model TGT memungkinkan siswa dapat belajar lebih rileks disamping menumbuhkan tanggung jawab, kerja sama, persaingan sehat dan keterlibatan belajar. Sedangkan menurut penelitian Triyani (2009), penggunaan model TGT dapat meningkatkan hasil belajar.

Selain menerapkan model pembelajaran, penggunaan media pembelajaran juga dapat dilakukan guru untuk meningkatkan hasil belajar matematika. Salah satu media yang dapat dapat diterapkan oleh guru pada saat pembelajaran yaitu dengan permainan. Ciri permainan adalah menciptakan suasana belajar yang menyenanngkan serta serius tapi santai (Sutikno, 2014). Salah satu permainan yang dapat digunakan adalah permainan monopoli. Permainan ini memiliki banyak komponen, warna dan tantangan sehingga dapat melatih ketelitian, kesabaran dan membuat suasana menyenangkan Arif \& Muji (Irwan, 2017). Dalam permainan monopoli setiap siswa akan mengumpulkan poin sebanyak mungkin agar menjadi pemenang, hal ini diharapkan bisa membuat suasana kelas menjadi aktif. Menurut penelitian Maghfiroh (2016) penggunaan permainan monopoli sebagai media pada model pembelajaran Teams Game Tournament (TGT) efektif terhadap hasil belajar. Berdasarkan latar belakang di atas, maka peneliti tertarik untuk melakukan penelitian dengan judul "Pengaruh Model Pembelajaran Teams Games Tournament dengan Permainan monopoli Terhadap Hasil Belajar Matematika di SMK Kolese Tiara Bangsa“.

\section{Metode Penelitian}

Jenis penelitian yang digunakan dalam penelitian ini adalah penelitian kuantitatif. Metode penelitian ini menggunakan penelitian kuasi eksperimen. Desain yang digunakan dalam penelitian ini merupakan Postesst-Only Control Design. Populasi dalam penelitian adalah seluruh siswa kelas X SMK Kolese Tiara Bangsa berjumlah 94 siswa. Pengambilan sampel pada penelitian ini adalah dengan menggunakan purposive sampling, maka ditunjuk kelas X MM dan kelas X TKJ. Variabel bebas dalam penelitian ini adalah model pembelajaran TGT dengan 
permainan monopoli dan model pembelajaran konvensional. Variabel terikat dalam penelitian ini adalah hasil belajar matematika. Instrumen yang digunakan dalam penelitian ini adalah instrument tes berupa soal essay yang telah diuji validitasnya menggunakan validitas konstruk dengan rumus product moment (Sudijono, 2012), tingkat kesukaran, daya pembeda dan reliabilitas menggunakan rumus Crobach's Alpha $(\alpha)$. Hasil dari koefisien Crobach's Alpha yaitu 0,69 sehingga memiliki kriteria reliabilitas yang tinggi (Sundayana, 2014). Sedangkan untuk uji prasyarat dalam penelitian ini adalah uji normalitas menggunakan rumus Kolmogorovsmirnov (Noor, 2013), dan uji homogenitas menggunakan uji F. Untuk analisis uji hipotesis menggunkanan uji one sampel t-test dan uji independent sampel t-test.

\section{Hasil Penelitian dan Pembahasan}

Hasil penelitian diperoleh nilai pada kelas eksperimen lebih tinggi dari pada kelas kontrolsebagaimana pada Tabel 2.

Tabel 2. Deskripsi Data Posttest

\begin{tabular}{ccc}
\hline Deskripsi Data & \multicolumn{2}{c}{ Post-Test } \\
\cline { 2 - 3 } & Kelas Eksperimen & Kelas Kontrol \\
\hline Rata-rata & 75,28 & 66,95 \\
Standar Deviasi & 13,54 & 15,03 \\
Varians & 183,31 & 225,94 \\
\hline
\end{tabular}

Sebelum data diuji hipotesis, terlebih dahulu data diuji normalitas dan homogenitasnya. Uji normalitas diperoleh nilai signifikansi kelas eksperimen dan kelas kontrol adalah 0,200, sehingga disimpulkan bahwa bahwa data kelas eksperimen dan kelas kontrol terdistribusikan secara normal. Selanjutnya uji homogenitas dengan membandingkan varians data dari nilai post-test, diperoleh $F_{\text {hitung }} \leq F_{\text {tabel }}$ sehingga dapat disimpulkan bahwa variansi data homogen.

Hipotesis pertama diuji dengan one sampel $t$-test diperoleh nilai $t_{\text {hitung }}(2,207)>t_{\text {tabel }}$ $(2,039)$ sehingga disimpulkan terdapat pengaruh model pembelajaran TGT dengan permainan monopoli terhadap hasil belajar matematika. Menurut Sari (2016) permainan monopoli juga membantu siswa untuk belajar memperoleh pengetahuan serta membangun konsep secara mandiri melalui pengalaman belajarnya dengan suasana yang menyenangkan. Siswa belajar lebih rileks dan setiap siswa bertanggung jawab terhadap kelompoknya karena mempunyai peranan penting. Hal ini sejalan dengan penelitian yang dilakukan oleh (Arfiani \& Rahim, 2015) pada siswa kelas VII SMPN Kendari dengan menyatakan bahwa model TGT memiliki pengaruh pada hasil belajar matematika. Penggunaan permainan monopoli juga sangat berpengaruh dalam meningkatkan hasil belajar siswa karena permainan ini tidak membosankan dan diketahui memiliki banyak komponen, sehingga bisa melatih ketelitian dan kesabaran siswa. Sama dengan pendapat Arif \& Muji (Irwan, 2017) satu dari banyaknya kelebihan permainan monopoli yaitu pemain dapat merasakan senang, dan muncul rasa ingin tahu yang tinggi.

Hipotesis kedua diuji dengan one sampel t-test diperoleh nilai $t_{\text {hitung }}(-0,907)<t_{\text {tabel }}$ (2,093), disimpulkan tidak adanya pengaruh model pembelajaran konvesional terhadap hasil 
belajar matematika. Pelaksanaan model pembelajaran konvensional tidak berpengaruh terhadap hasil belajar matematika karena suasana kelas kurang begitu aktif dan siswa cenderung tidak berpartisipasi selama proses pembelajaran. Pada kegiatan pembelajaran siswa hanya mendengarkan dan mencatat, ini membuat suasana belajar di kelas sangat mononton dan kurang menarik. Senada dengan (Sutikno, 2014) aktifitas peserta didik dalam pembelajaran menggunakan metode ceramah atau pembelajaran konvensional hanya menyimak sambil sesekali mencatat dan proses pembelajaran yang menggunakan metode ini perhatian terpusat pada guru, sedangkan peserta didik hanya menerima secara pasif.

Uji hipotesis ketiga diperoleh nilai $t_{\text {hitung }}(2,069)$ lebih besar dari $t_{\text {tabel }}(2,008)$ sehingga disimpulkan terdapat perbedaan pengaruh model TGT dengan permainan monopoli dan model konvensional terhadap hasil belajar matematika. Dari proses pembelajaran yang telah dilaksanakan dapat disimpulkan bahwa adanya perbedaan hasil belajar matematika antara model pembelajaran TGT dengan permainan monopoli dan pembelajaran konvensional disebabkan saat penggunakan model TGT dengan permainan monopoli siswa belajar lebih rileks, dan lebih bertanggung jawab atas dirinya sendiri maupun kelompoknya. Hal ini relevan dengan hasil penelitian Yunus (2017) yang menggunakan model pembelajaran TGT dengan model konvensional di kelas XI Mia SMA Negeri 2 Pangkajene.

\section{Kesimpulan}

Model pembelajaran TGT dengan permainan monopoli dan model konvensional memiliki pengaruh yang berbeda terhadap hasil belajar matematika siswa SMK Tiara Bangsa. Oleh karena itu, dalam kegiataan pembelajaran, guru harus dapat memilih model ataupun pendekatan pembelajaran yang sesuai karakteristik siswa sehingga dapat mengoptimalkan hasil belajar matematika siswa. Model pembelajaran TGT dengan permainan monopoli dapat digunakan sebagai salah satu alternatif dalam kegiatan pembelajaran.

\section{Daftar Pustaka}

Arfiani, \& Rahim, U. (2015). Pengaruh Model Pembelajaran Kooperatif Tipe TGT (Teams Games Tournament) Terhadap Hasil Belajar Matematika Siswa Kelas VII SMPN 10 Kendari. Jurnal Penelitian Pendidikan Matematika, 3(1), 1-16.

Arsyad, A. (2016). Media Pembelajaran. Jakarta: PT RajaGrafindo Persada.

Irwan, D. (2017). Pengembangan Media Permainan (Game) Monopoli Pada Pembelajaran Fisika Materi Besaran Dan Satuan Pada Tingkat Sekolah Menengah Pertama (SMP). Universitas Islam Negeri AR-Raniry.

Maghfiroh, A. (2016). Efektivitas Penggunaan Permainan Monopoli Pada Materi Sistem Ekskresi Sebagai Media Pembelajaran Teams Games Tournament (TGT) Terhadap Hasil Belajar Siswa Kelas XI SMAN 11 Semarang. Universitas Islam negeri Walisongo

Noor, J. (2013). Metodologi Penelitian: Skripsi, Tesis, Disertasi, Dan Karya Ilmiah (3rd ed.). 
Suryani, Agustyaningrum \& Hasibuan; Pengaruh Model Pembelajaran Teams Games Touraments....

Jakarta: Kencana Prenada Media Group.

Nur Wahyuninsih Yunus. (2017). Perbedaan Hasil Belajar Siswa yang Diajar Menggunakan Model Pembelajaran Teams Games Tournaments ( TGT ) dengan Model Pembelajaran Konvensional Di Kelas XI Mia SMA Negeri 2 Pangkajene ( Studi pada Materi Pokok Asam Basa ). Jurnal Chemica, 18(01), 56-63.

Purwanto, \& Juwariah Annisa. (2016). Pengaruh Model Pembelajaran Kooperatif Tipe Teams Games Tournament (TGT) Menggunakan Media Permainan Monopoli Terhadap Hasil Belajar Fisika Siswa Pada Materi Fluida Statis. Ikatan Alumni Fisika Universitas Negeri Medan, 2, 39.

Roqimah, S. (2011). Upaya Meningkatkan Hasil Belajar Biologi Menggunakan Strategi Role Playing Dan Media Macromedia Flash Pada Materi Sistem Pernapasan Manusia Siswa Kelas VIII Di SMP Muhammadiyah 5 Surakarta Tahun Ajaran 2010/2011. Universitas Muhammadiyah Surakarta.

Sari, S. A.(2016). Penerapan Model Pembelajaran Kooperatif Tipe TGT (Teams Games Tournament) dengan Menggunakan Media Permainan Monopoli Terhadap Hasil Belajar Siswa SMP Pada Materi Pemuaian. Jurnal Inovasi Pendidikan Fisika (JIPF). Universitas Negeri Surabaya.

Shoimin, A. (2014). Model Pembelajaran Inovatif dalam Kurikulum 2013 (Cetakan 1). Yogyakarta: AR-Ruzz Media.

Simanungkalit, N. A. dan H. T. (2014). Pengaruh Penggunaan Media Pembelajaran Mind Mapping Terhadap Prestasi Belajar Matematika Siswa Kelas VII SMP Tunas Baru JinSeung Batam Tahun Ajaran 2014/2015. 2(1), 32-37.

Sudijono, A. (2012). Pengantar Statistik Pendidikan (24th ed.). Jakarta: PT RajaGrafindo Persada.

Sugiyono. (2017). Metode Penelitian Kuantitatif,Kualitatif, Dan R\&D. Bandung: Alfabeta.

Sundayana, R. (2014). Statistika Penelitian Pendidikan. Bandung: Alfabeta,CV.

Sutikno, S. (2014). Metode \& Model-Model Pembelajaran (1st ed.; P. Hadisaputra, Ed.). Lombok: Holistica.

Syahsiyha. (2008). Pengaruh Penggunaan Permainan Monopoli Sebagai Media Pengajaran Matematika Terhadap Minat Belajar Matematika Siswa Sekolah Dasar (Studi Eksperimen di SDIT AL-HIKMAH Pela Mampang Kelas V Pada Pokok Bahasan Bangun Datar). Animal Genetics, 39(5), 561-563.

Triyani, A. N. (2009). Model Pembelajaran Kooperatif Tipe Teams - Games - Tournament (TGT) Sebagai Upaya Meningkatkan Keaktifan Belajar Matematika Siswa Pada Pokok Bahasan Peluang Dan Statistika Di SMP Negeri 4 Depok Yogyakarta Kelas IX C. 